\title{
Taxonomic status of Atocion hypanicum (Klokov) Tzvelev (Caryophyllaceae) inferred from analysis of ITS1 and ITS2 secondary structure
}

\author{
VIKTORIIA O. MARTYNYUK \\ OKSANA V. TYSHCHENKO \\ NATALIIA I. KARPENKO \\ ANDRII S. TARIEIEV \\ IHOR YU. KOSTIKOV
}

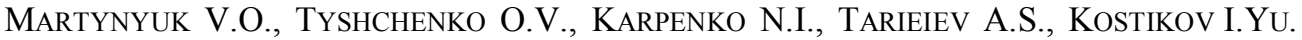
(2014). Taxonomic status of Atocion hypanicum (Klokov) Tzvelev (Caryophyllaceae) inferred from analysis of ITS1 and ITS2 secondary structure. Chornomors' $k$. bot. $z$., 10 (4): 416-425. doi:10.14255/2308-9628/14.104/1.

\begin{abstract}
Secondary structures of ITS1 and ITS2 transcripts of Atocion hypanicum (Klokov) Tzvelev and A. compactum (Fisch. ex Hornem.) Tzvelev were reconstructed. The presence of a unique nucleotide substitution in fourth helix of $A$. hypanicum ITS1 transcript, which lead to a disturbance in the secondary structure of the helix, strongly supported it as a separate operational taxonomic unit. The lack of CBC in obtained sequences of ITS2 from A. hypanicum and A. compactum confirmed the absence of genetic barriers for the taxa crossing. Phenotypical distinctions between A. hypanicum and A. compactum from Caucasus associated with bracts and the morphology of the uppermost leaves are demonstrated. The separate species status of $A$. hypanicum was confirmed.
\end{abstract}

Key words: Atocion hypanicum, A. compactum, ITS1 and ITS2 secondary structure, taxonomic status

МАРТИНЮК В.О., ТИЩЕНКО О.В., КАРПЕНКО Н.І., ТАРєЕВ А.С., КОСТІКОВ І.Ю. (2014). Таксономічний статус Atocion hypanicum (Klokov) Tzvelev (Caryophyllaceae) за результатами аналізу вторинної структури нуклеотидних послідовностей ITS1 та ITS2. Чорноморськ. бот. ж., 10 (4): 416-425. doi:10.14255/2308-9628/14.104/1.

Проведено реконстукцію вторинних структур послідовностей ITS1 та ITS2 транскриптів Atocion hypanicum (Klokov) Tzvelev та A. compactum (Fisch. ex Hornem.) Tzvelev. Наявність унікальної нуклеотидної заміни у четвертій спіралі транскрипту послідовності ITS1 A. hypanicum, що призводить до порушення вторинної структури спіралі, вказує на статус цього таксону як окремої операційної таксономічної одиниці. Відсутність СВC в послідовності ITS2 між отриманими сіквенсами A. hypanicum та A. compactum свідчить про відсутність генетичних бар'єрів для схрещування цих таксонів. Показано наявність фенотипних відмін між A. hypanicum та A. compactum 3 території Кавказу, пов'язаних 3 морфологією приквіток та верхівкових листків. Підтверджено самостійний видовий статус A. hypanicum.

Ключові слова: Atocion hypanicum, Atocion compactum, вторинна структура ITS1 та ITS2, таксономічний статус

МАРТЫНЮК В.А., ТЫЩЕНКО О.В., КАРПЕНКО Н.И., ТАРЕЕВ А.С., КОСТИКОВ И.Ю. (2014). Таксономический статус Atocion hypanicum (Klokov) Tzvelev (Caryophyllaceae) флоры Украины по результатам анализа вторичной структуры нуклеотидных последовательностей ITS1 и ITS2. Черноморск. бот. ж., 10 (4): 416-425. doi: $10.14255 / 2308-9628 / 14.104 / 1$.

(C) В. О. Мартинюк, О. В. Тищенко, Н. І. Карпенко, А. С. Тарєєв, І. Ю. Костіков Чорноморськ. бот. ж., 10 (4): 416-425. 
Проведена реконструкция вторичных структур последовательностей транскриптов ITS1 и ITS2 Atocion hypanicum (Klokov) Tzvelev и A. compactum (Fisch. ex Hornem.) Tzvelev. Наличие уникальной нуклеотидной замены в четвертой спирали транскрипта последовательности ITS1 A. hypanicum, которая приводит к нарушению вторичной структуры спирали, указывает на статус этого таксона как самостоятельной операционной таксономической единицы. Отсутствие СВС в последовательности ITS2 между полученными сиквенсами A. hypanicum и A. compactum свидетельствует о отсутствии генетических барьеров для скрещивание этих таксонов. Показано наличие фенотипических отличий между $A$. hypanicum и $A$. compactum с територии Кавказа, связаных с морфологией прицветников и верхушечных листьев. Подтвержден самостоятельный видовой статус $A$. hypanicum.

Ключевые слова: Atocion hypanicum, Atocion compactum, вторичная структура ITS1 $и$ ITS2, таксономический статус

Atocion hypanicum (Klokov) Tzvelev (basionym Silene hypanica Klokov) was described in 1948 by M.V. Klokov from Pobuzhzya granite outcrops as a new species $S$. hypanica inside the genus Silene L. [KLOKOV, 1948]. Klokov also noted that earlier on the territory of Ukraine this plant was identified as $S$. compacta Fisch. - a species, described by F. Fischer in 1812 from Caucasus. Additionally, he noticed that S. hypanica is an endemic of granitic outcrops of Pivdenny Bug. In 2001 S. hypanica was transferred to the genus Atocion Adans. by N.N. Tzvelev [TzVELEV, 2001]. In agreement with his predecessors, [FLORA..., 1952; Mosyakin, FedoronchuK, 1999], he considered A. hypanicum to be a separate species, related to A. compactum (Fisch. ex Hornem.) Tzvelev (basionym Silene compacta).

In the domestic literature Atocion hypanicum is now considered to be a strict local endemic of Pivdenny Bug, included in different Ukrainian issues of nature conservation and referred as "vunerable" [Opredelitel..., 1987; ChervonA..., 1996, 2009; FedOrOnCHuK, DIDUKH, 2002]. Several localities of this species are known. All of them are located on the south spurs of Pryniprovska highland, within the boundaries of Right Bank Steppe, in Pivdenny Bug valley. Local populations have small area, compact-diffuse structure and are stably decreasing [FEDORONCHUK M.M., DidUKH YA. P. et al., 2002; CHERVONA..., 2009]. In 1991 Silene hypanica was placed to European Red List [EUROPEAN ..., 1991], but in 2011 [BILZ et al, 2011] this species was not included there.

Likely, the reason for S. hypanica's removal from the European Red List is change in the understanding of $S$. compacta volume in 1990-s. In particular, S. hypanica was considered as a probable synonym of $S$. compacta in West-European literature [TUTIN et al., 1993]. It should be mentioned, that the tendency for the enlargement of $S$. compacta appeared earlier. In 1967 S. vandasii Nábělek, described in 1923 from south-east Turkey [FLORA ..., 1967], was included into S. compacta. Additionally, we emphasize, that both viewpoints: for separateness of $S$. hypanica and volume of $S$. compacta were based exclusively on the results of comparison of morphological descriptions and herbarium specimens.

In 2009, in order to unravel the phylogenetic relationships between genera Atocion and Viscaria Bernh., a molecular analysis was performed. 6 sequences of nuclear (including ITS 1 and ITS2) and chloroplast DNA markers were obtained for five samples, named Atocion compactum by the authors [FRAJMAN et al., 2009]. The material, used in this research, was collected on the territory of Turkey, Georgia and Macedonia. Moreover, one sample, described as cultivar seeds of $A$. compactum from $\mathrm{Ukraine}^{1}$, but without any notices about its possible connection to A.hypanicum was investigated in the study. The material from $A$. hypanicum type locality was not yet included in the research. Therefore, the questions

1 According to NCBI annotation this material is received from UPS herbarium (specimen 330 from A.Rautenberg collection) which according to publication is called "Cultivated: seeds from Ukraine" [FRAJMAN et al., 2009]. However, according to collector's private label specimen source is unknown (www.sileneae.info $)$. Further we will call this specimen "Ukrainian cultivar". 
about status and volume of $A$. compactum, as well as separateness of $A$. hypanicum were left without discussion. Hence, the taxonomical status of $A$. hypanicum remains unclear.

The purpose of our research was to clarify the taxonomic status of A. hypanicum on the basis of comparative analysis of the original molecular data obtained from type locality of A. hypanicum on the territory of Ukraine and A. compactum from Caucasus, and also sequences from the same species deposited in NCBI. We analyzed the structure of marker sequences from ITS1-5,8S-ITS2 cluster of ribosomal genes with estimation of taxonomic weights of discriminant phenotypic traits between A. compactum and A. hypanicum.

\section{Matherials and methods}

Material: the original samples from the type locality of A. hypanicum (vicinity of Bogdanivka, Domanivka distr., Mykolaiv reg., Ukraine) and A. compactum from Caucasus (vicinity of Dombay, Karachay-Cherkess Republic, Russian Federation), and also 29 herbarium specimens from two herbaria of Ukraine (KW and KWU).

Leaves' fragments of herbarium specimen of A. hypanicum (KW №081628) and seedlings of $A$. compactum were used for molecular analysis. Total DNA extraction was performed using a modified CTAB-method [TARIEIEV et al., 2011]. ITS1-5,8S-ITS2 sequence amplification of $A$. hypanicum was performed using ITS1 and ITS4 primers. The same sequence of $A$. compactum was obtained using ITS4 and ITS5 primers (table 1) on Techne thermocycler according to White [WHITE, 1990]. Sequencing of amplicons with forvard and reverse primers was done commercially in Macrogen Inc. (http://www.Macrogen.com, Netherlands).

Послідовність праймерів, використаних для ампліфікації та секвенування

Таблиця 1

Primer sequences, used for amplification and sequencing

Table 1

\begin{tabular}{|l|l|}
\hline Назва праймера & Послідовність \\
\hline ITS1-forvard & 5'-TCCGTAGGTGAACCTGCGG-3' \\
\hline ITS4-reverse & 5'-TCCTCCGCTTATTGATATGC-3' \\
\hline ITS5-forvard & 5'-GGAAGTAAAAGTCGTAACAAGG-3' \\
\hline
\end{tabular}

Sequences were edited with BioEdit software [HALL, 1999] through forward and reverse chromatogram comparison. Obtained sequences were deposited in NCBI (accession number KJ616753 and KM975935).

ITS1 sequence was annotated in accordance to A. compactum (accession number FJ384030), ITS2 annotation was done by the modeling of terminal part of 5.8S sequence and its complementary part of $28 \mathrm{~S}$ in MFold [ZUKER, 2003]. Screening of NCBI nucleotide collection was performed using BLAST (blast.ncbi.nlm.nih.gov) [ALTSCHUL et al., 1990]. The data set for comparison of secondary structures included original data on $A$. compactum and A. hypanicum as well as other sequences of $A$. compactum from GeneBank with the next NCBI accession numbers: FJ384028 and FJ384029 (Turkey), FJ384030 (Georgia), FJ384031 (Macedonia), FJ384032 ("Ukrainian cultivar"). ITS2 secondary structure reconstruction was done by online service MFold [ZUKER, 2003]. Obtained structures were visualized in Pseudoviewer 3.0 [BYUN et al., 2009].

Comparative morphological analysis was performed on the basis of originally collected material and herbarium samples mentioned above. The sample of cultivar of A. compactum, collected in Sevastopol (KW №014166) was also included in the research.

\section{Results}

Molecular-genetic analysis. Obtained ITS1-5.8S-ITS2 sequences of A. hypanicum (646 bp.) and $A$. compactum (628 bp.) were most similar (over $98 \%$ ) to five sequences, which 
were deposited as A. compactum (NCBI accession numbers FJ384028, FJ384029, FJ384030, FJ384031, FJ384032), according to the results of BLAST search. The sequences of A. compactum from the territory of Macedonia (FJ384031) and Turkey (FJ384029) were most similar to A. hypanicum ( $99.69 \%$ and $99.36 \%$ of identity, respectively). The sequences of samples from Georgia (FJ384030) and so called "Ukrainian cultivar" (FJ384032) displayed lower similarity (98.76\% and $99.07 \%$, respectively). The last sample (FJ384028, Turkey) shared $98,89 \%$ of similarity, but all eight different positions contained ambiguously identified nucleotides. The similarity of original A. compactum sequence to the described sequences was as following: FJ384031 - $100 \%$, FJ384032 - 99,36 \%, FJ384030 - 99,04 \%, FJ384029 - 99,68 \% and FJ384028 - 98,88 \%.

In total 10 variable positions for ITS1 and 4 - for ITS2 were detected in sampling (tab. 2).

Таблиця 2

Варіабельні сайти ITS1 та ITS2 послідовностей $A$. hypanicum та $A$. compactum

Table 2

Variable sites in ITS1 and ITS2 sequences of $A$. hypanicum and $A$. compactum

\begin{tabular}{|c|c|c|c|c|c|c|c|c|c|c|c|c|c|c|}
\hline & \multicolumn{10}{|c|}{ ITS1 } & \multicolumn{4}{|c|}{ ITS2 } \\
\hline $\begin{array}{l}\text { Position of variable site } \\
\text { in sequence } \rightarrow\end{array}$ & 58 & 69 & 74 & 77 & 80 & 102 & 125 & 133 & 210 & 216 & 40 & 80 & 130 & 189 \\
\hline $\begin{array}{l}\text { A.hypanicum } \\
\text { KJ616753 (UA) }\end{array}$ & $\mathrm{C}$ & $\mathrm{T}$ & $\mathrm{C}$ & $\mathrm{C}$ & $\mathrm{C}$ & G & $\mathrm{C}$ & $\mathrm{C}$ & $\begin{array}{l}\mathrm{S} \\
(\mathrm{C})\end{array}$ & G & $\mathrm{C}$ & $\mathrm{A}$ & $\mathrm{C}$ & $\mathrm{T}$ \\
\hline A.compactum (RU) & $\mathrm{C}$ & $\mathrm{T}$ & $\mathrm{C}$ & $\mathrm{C}$ & $\mathrm{C}$ & $\mathrm{G}$ & $\mathrm{C}$ & $\mathrm{C}$ & $\mathrm{G}$ & $\mathrm{G}$ & $\mathrm{C}$ & A & $\mathrm{C}$ & $\mathrm{T}$ \\
\hline $\begin{array}{l}\text { A.compactum } \\
\text { FJ384030 (GE) }\end{array}$ & $\mathrm{C}$ & $\mathrm{Y}$ & $\mathrm{C}$ & $\mathrm{C}$ & $\mathrm{Y}$ & $\mathrm{R}$ & $\mathrm{C}$ & $\mathrm{C}$ & $\mathrm{G}$ & $\mathrm{G}$ & $\mathrm{C}$ & $\mathrm{A}$ & $\mathrm{T}$ & $\mathrm{Y}$ \\
\hline $\begin{array}{l}\text { A.compactum } \\
\text { FJ384031 (MC) }\end{array}$ & $\mathrm{C}$ & $\mathrm{T}$ & $\mathrm{C}$ & $\mathrm{C}$ & $\mathrm{C}$ & $\mathrm{G}$ & $\mathrm{C}$ & $\mathrm{C}$ & G & G & $\mathrm{C}$ & A & $\mathrm{C}$ & $\mathrm{T}$ \\
\hline $\begin{array}{l}\text { A.compactum } \\
\text { FJ384029 (TR2) }\end{array}$ & $\mathrm{C}$ & $\mathrm{T}$ & $\mathrm{T}$ & $\mathrm{C}$ & $\mathrm{C}$ & $\mathrm{G}$ & $\mathrm{C}$ & $\mathrm{C}$ & $\mathrm{G}$ & $\mathrm{T}$ & $\mathrm{C}$ & A & $\mathrm{C}$ & $\mathrm{T}$ \\
\hline $\begin{array}{l}\text { A.compactum } \\
\text { FJ384028 (TR1) }\end{array}$ & $\mathrm{Y}$ & $\mathrm{T}$ & $\mathrm{C}$ & $\mathrm{Y}$ & $\mathrm{C}$ & G & $\mathrm{Y}$ & $\mathrm{M}$ & G & G & $\mathrm{Y}$ & W & $\mathrm{C}$ & $\mathrm{T}$ \\
\hline $\begin{array}{l}\text { A.compactum } \\
\text { FJ384032 (UAc) }\end{array}$ & $\mathrm{C}$ & $\mathrm{C}$ & $\mathrm{C}$ & $\mathrm{C}$ & $\mathrm{T}$ & G & $\mathrm{C}$ & $\mathrm{C}$ & G & G & $\mathrm{C}$ & A & $\mathrm{T}$ & $\mathrm{C}$ \\
\hline $\begin{array}{l}\text { Type of changes in } \\
\text { secondary structure }\end{array}$ & SNP & $\begin{array}{l}\text { nst, S } \\
\text { NP }\end{array}$ & $\mathrm{hCBC}$ & SNP & $\begin{array}{l}\text { hCBC } \\
\text { SNP }\end{array}$ & SNP & SNP & SNP & sst & sst & SNP & SNP & nst & $\begin{array}{l}\text { sst, } \\
\text { SNP }\end{array}$ \\
\hline
\end{tabular}

Abbreviations: SNP - single nucleotide polymorphism; nst - nonstructural substitution; sst structural substitution; hCBC - hemicompensatory base change.

The results of ITS1 secondary structure comparison of A. hypanicum and A. compactum and also A. compactum sequences, deposited in NCBI, revealed that analyzed sequences are heterogeneous. Two hemicompensatory base changes are present in positions 74 and 80 of FJ384029 and FJ384032 respectively. Also one nonstructural substitution in the terminal part of the first helix of A. compactum (FJ384032, position № 69) was observed (fig. 1) and a range of ambiguous sites (positions № 58, 69, 77, 80, 125 and 133) were detected in some sequences of $A$. compactum.

A. hypanicum can be distinguished from all analyzed $A$. compactum sequences by the substitution in position № 210 in ITS1 sequence. In this position cytosine was present for A. hypanicum (instead of guanine for $A$. compactum). The presence of guanine minor peak in the sequence of A. hypanicum (fig. 2) can be argued by polycopycity of ribosomal genes. Nucleotide substitution in position № 210. C $>$ G was structural (sst) and caused changes in the secondary structure of fourth helix.

The secondary structure analysis of ITS2 of A. hypanicum and A. compactum (fig. 3) demonstrated a total identity of primary and secondary structures of 1 st and 2 nd helices within a whole sampling. Two ambiguous nucleotides ( $\mathrm{Y}$ in 40 -th position and $\mathrm{W}$ in 80 -th position) were found for the sample from Turkey (FJ384028). 
In the variable part of ITS2 3-rd helix (position №130) the nucleotide substitution was present in two samples of $A$. compactum (FJ384030, Georgia та FJ384032, "Ukrainian cultivar"), but the secondary structure of third helix remained identical for both samples.

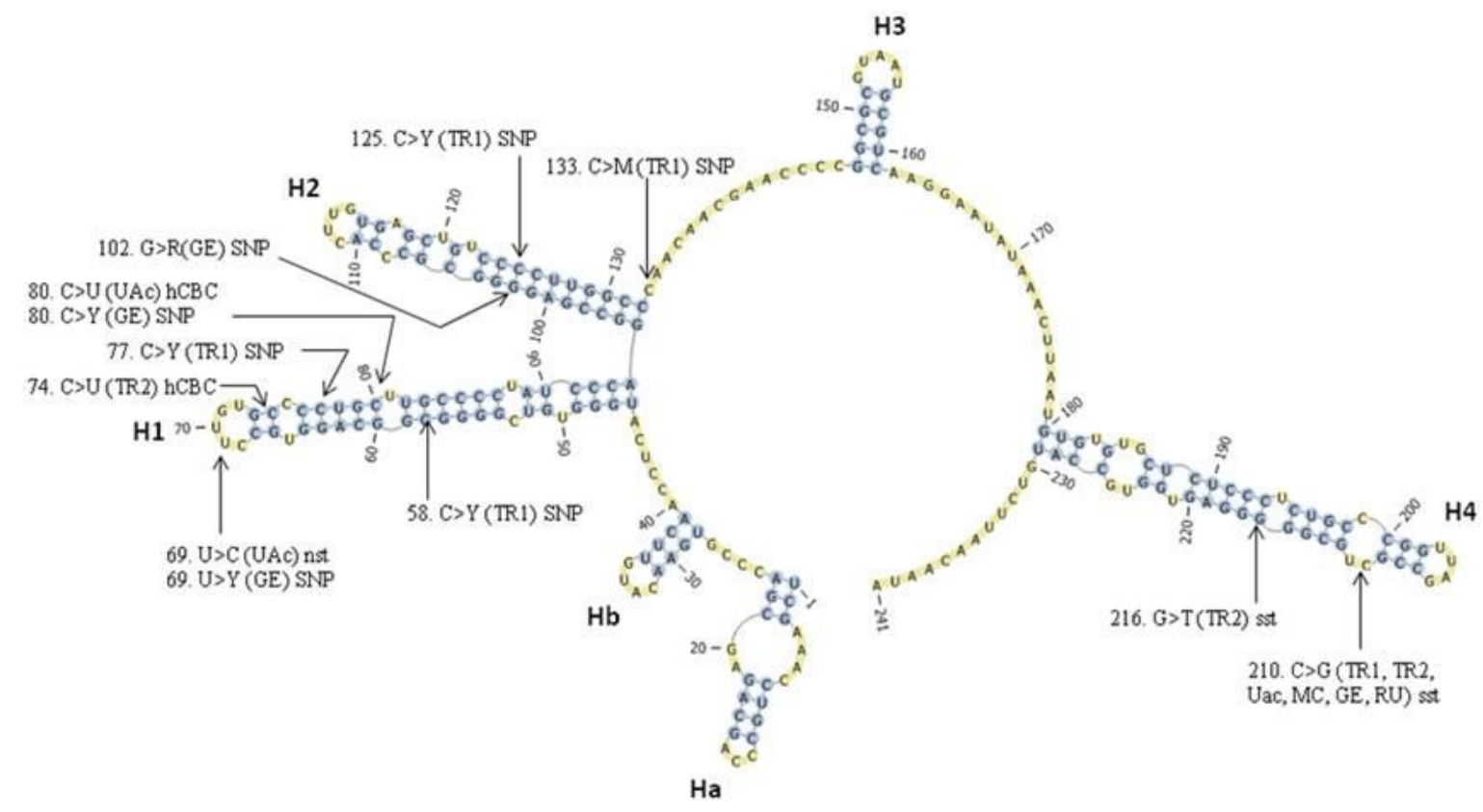

Рис. 1. Вторинна структура послідовності ITS1 Atocion hypanicum (Klokov) Tzvelev 3 позначенням відмін у ITS1 $A$. compactum (Fisch. ex Hornem.) Tzvelev: На, Нb - додаткові спіралі, Н1 - перша спіраль, Н2 - друга спіраль, Н3 - третя спіраль, Н4 - четверта спіраль; UАс “український культивар" FJ384032, GE - зразок з Грузії FJ384030, МС - зразок 3 Македонії (FJ384031), RU - оригінальний сиквенс $A$. compactum 3 Російської Федерації, TR1 (FJ384028) та TR2 (FJ384029) - зразки з Туреччини.

Fig. 1. ITS1 secondary structure of Atocion hypanicum (Klokov) Tzvelev showing the differences in ITS1 of $A$. compactum: Ha, Hb - additional helixes, H1 - first helix, H2 - second helix, H3 - third helix, H4- fourth helix; UAc - "Ukrainian cultivar" FJ384032, GE - specimen from Georgia FJ384030, MC specimen from Macedonia (FJ384031), TR1 (FJ384028) and TR2 (FJ384029) - specimens from Turkey.

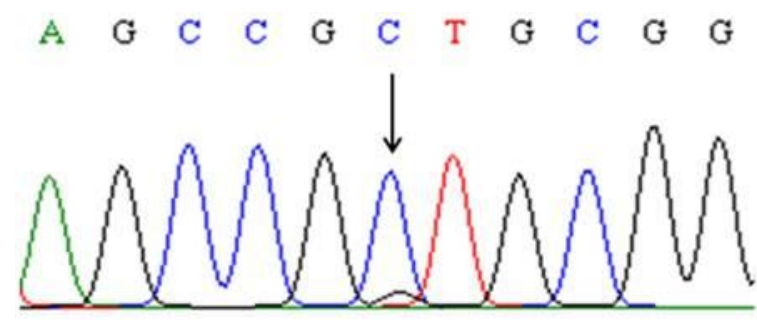

1

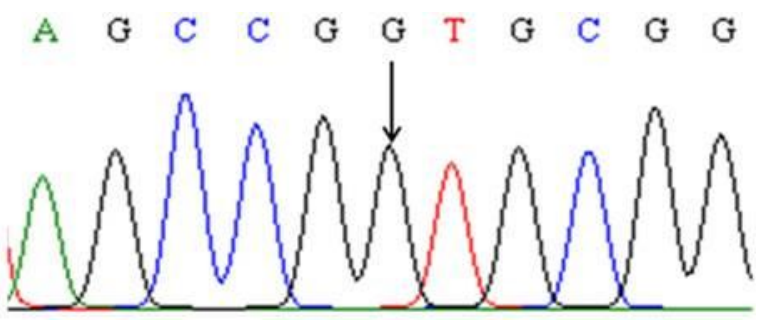

2

Рис. 2. Фрагменти хроматограм, що ілюструють абсолютне переважання цитозину в 210-му сайті послідовності ITS1 Atocion hypanicum (Klokov) Tzvelev (1) та гуаніну в $A$. compactum (Fisch. ex Hornem.) Tzvelev (2).

Fig. 2. ITS1 chromatogram fragments showing cytosine peak in Atocion hypanicum (Klokov) Tzvelev sequence (1) and guanine peak in A. compactum (Fisch. ex Hornem.) Tzvelev sequence (2).

Based on the sequence of fourth helix of ITS2 a total sampling can be divided into 3 groups according to the type of nucleotide in position № 189: the sequences of A. hypanicum and A. compactum from Turkey (FJ384028, FJ384029), Macedonia (FJ384031) and original 
sequence of the sample from Russian Federation had $\mathrm{T}$ in position № 189, whereas the "Ukrainian cultivar" of $A$. compactum (FJ384032) had C in the same position, and sequence of the sample from Georgia (FJ384030) contained ambiguous nucleotide (C or T).

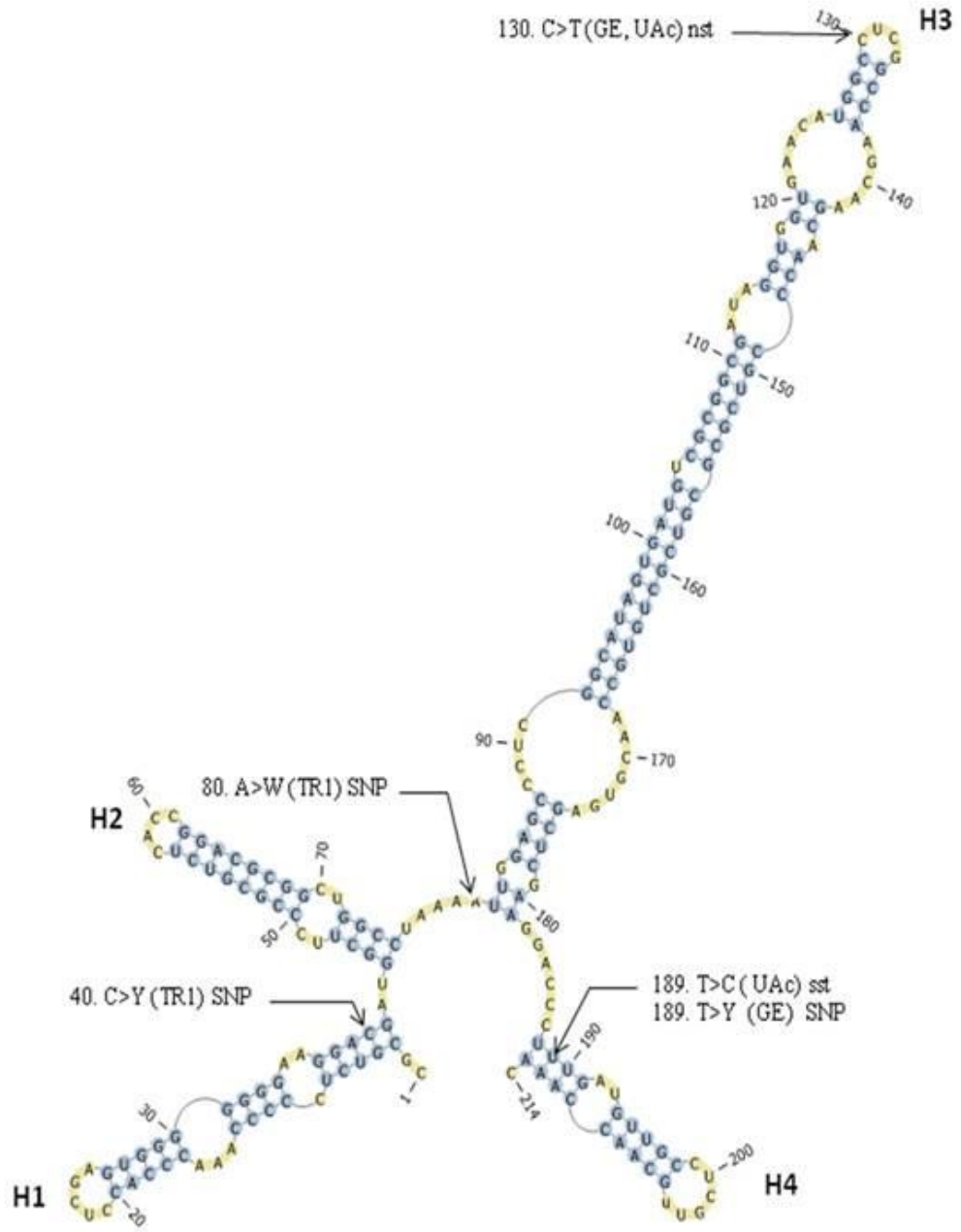

Рис. 3. Вторинна структура послідовності ITS2 Atocion hypanicum (Klokov) Tzvelev 3 позначенням відмін у ITS2 A. compactum: H1 - перша спіраль; Н2 - друга спіраль; Н3 - третя спіраль; H4 - четверта спіраль; UAc - “український культивар" FJ384032, GE - зразок з Грузії FJ384030, TR1 - зразок з Туреччини FJ384028.

Fig 3. ITS2 secondary structure of Atocion hypanicum (Klokov) Tzvelev showing the differences in ITS2 of $A$. compactum (Fisch. ex Hornem.) Tzvelev: H1 - first helix, H2 - second helix, H3 - third helix, H4 - fourth helix; UAc - «Ukrainian cultivar» FJ384032, GE - specimen from Georgia FJ384030, TR1 specimen from Turkey FJ384028.

Morphological analysis. The comparison of herbarium samples of $A$. compactum from Caucasus and A. hypanicum from the valley of Pivdenny Bug (where locus classicus for every studied species is located) confirmed morphological differences between the studied taxa. A. compactum and A. hypanicum can be distinguished by bracts (membranaceous with brownish middle rib for $A$. compactum; herbaceous with membranaceous edges for A. hypanicum) and upper (apical) leaves (completely memranaceous for A. compactum; herbaceous with membranaceous edges for $A$. hypanicum). That fully agreed with literature data [KLOKOV, 1948; FLORA..., 1952; FEDORONCHUK, 1997; FLORA..., 2004].

Regarding the length of bracts and the ratio between calyx and capsule length, which were proposed earlier for discrimination between the two species [KLOKOV, 1948; FLORA ..., 1952; FLORA..., 2004], we observed no hiatus present between A. compactum and 
A. hypanicum. Moreover, according to the above mentioned literature data, A. compactum and A. hypanicum can be distinguished by the shape of calyx tooth (obtuse tooth for A. compactum and acute - for A. hypanicum). On the contrary, some herbarium specimens from Caucasus, identified as $A$. compactum, had acute calyx tooth.

To summarize, the population of $A$. compactum from Caucasus can be distinguished from the population of $A$. hypanicum from the territory of Ukraine only by the bacts and apical leaves.

\section{Discussion}

The absence of any CBC (compensatory base changes) between A. hypanicum and A. compactum according to A. Coleman concept claims the absence of genetic barriers for breeding between these taxa [COLEMAN, 2003, 2007, 2009].

The analysis of the secondary structures of ITS1 and ITS2 transcripts confirmed three distinct variants of the first and two variants of the fourth ITS1 helices as well as two variants of ITS2 fourth helix (fig. 4). According to these data, the investigated sampling can be divided into 4 main operation taxonomic unites (OTU) (tab. 3).
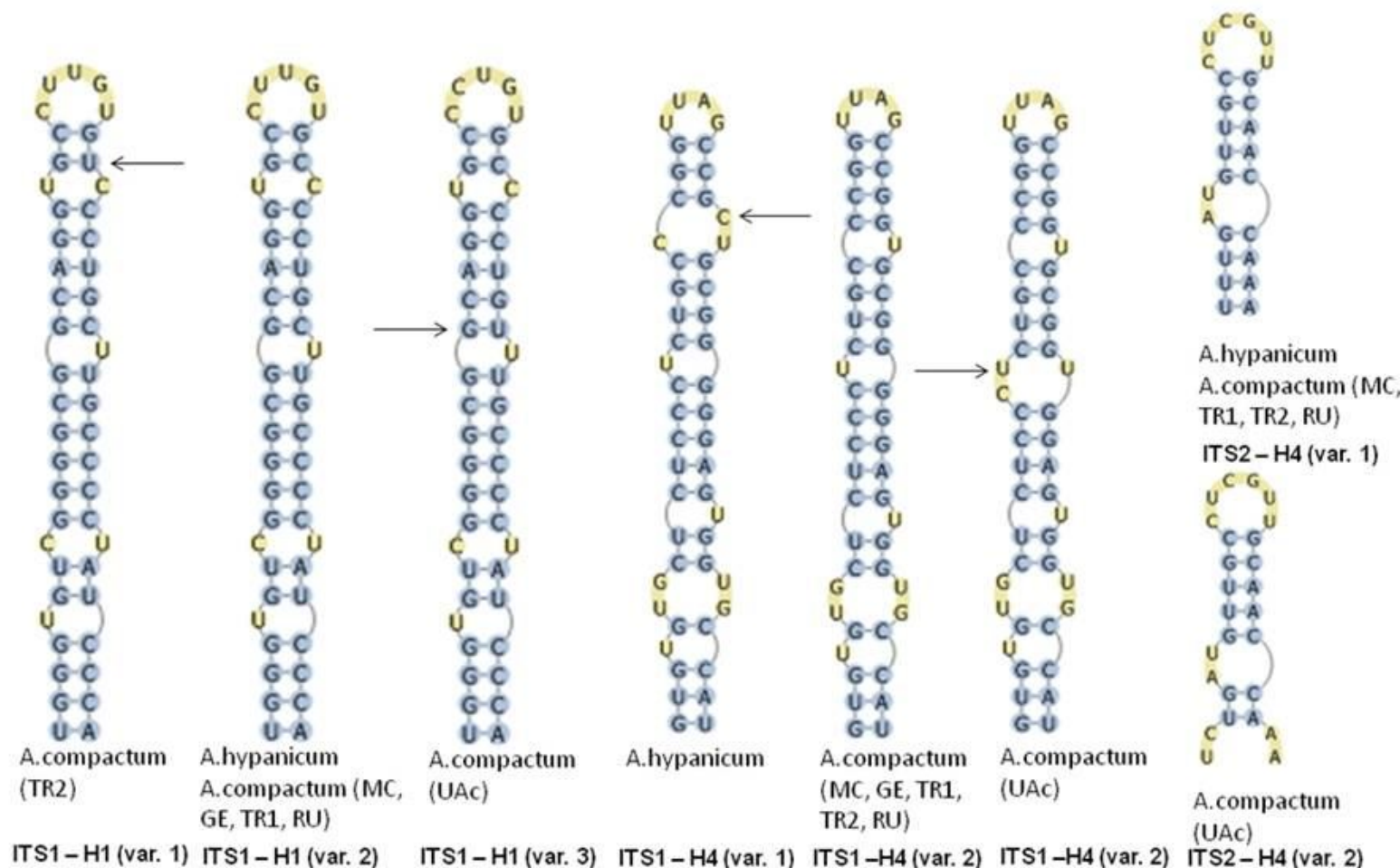

Рис. 4. Варіанти вторинних структур першої та четвертої спіралей ITS1, а також четвертої спіралі послідовності ITS2 Atocion hypanicum (Klokov) Tzvelev та A. compactum (Fisch. ex Hornem.) Tzvelev

Fig. 4. A. hypanicum and A. compactum (Fisch. ex Hornem.) Tzvelev secondary structure variants of ITS1 first and fourth helixes and of ITS2 fourth helix

Unique base change in A. hypanicum ITS1 fourth helix (site № 210) causes changes in the secondary structure and distinguish it from the other sequences of $A$. compactum. The second OTU is represented by the original sequence of A. compactum from Russian Federation and by the sequences from Macedonian (FJ384031) and Turkish (FJ384028) samples. The third OTU is represented by the sample from Turkey (FJ384029), and the fourth one - by "Ukrainian cultivar" (FJ384032). Although, the sample from Georgia (FJ384030) contains Y in position 189 of ITS2 and, therefore, can be placed into the both variants of helix 
structure, but with higher probability it belongs to OTU2 than to OTU4 on the basis of differences in first helix of ITS1.

Finally, rating of $A$. hypanicum as the separate OTU and also presence of morphological differences from A. compactum provide evidence that A. hypanicum is a separate endemic species.

Since A. compactum was described from the territory of Russia [FLORA..., 1936], the second OTU most likely represents a classic A compactum. The sample of $A$. compactum (FJ384029), originated from Turkey, is not identical to another Turkish sample (FJ384028) and represents the separate OTU. Possibly, this sample fit $S$. vandasii, which is considered as a synonym of $A$. compactum now. But since we had no specimens from locus classicus of Silene vandasii there was no opportunity to investigate them.

Таблиця 3

Варіанти вторинних структур спіралей ITS1 і ITS2 послідовностей та операційні таксономічні одиниці, що їм відповідають

Table 3

ITS1 and ITS2 helices' variants and corresponding operational taxonomic units

\begin{tabular}{|c|c|c|c|c|}
\hline & ITS1-H1 & ITS1-H4 & ITS2-H4 & \\
\hline A.hypanicum (UA) KJ616753 & var. 2 & var. 1 & var. 1 & OTU1 \\
\hline A.compactum (RU) & var. 2 & var. 2 & var. 1 & \multirow{4}{*}{ OTU2 } \\
\hline A.compactum FJ384031 (MC) & var. 2 & var. 2 & var. 1 & \\
\hline A.compactum FJ384030 (GE) & var. 2 & var. 2 & var. $1 / 2$ & \\
\hline A.compactum FJ384028 (TR1) & var. 2 & var. 2 & var. 1 & \\
\hline A.compactum FJ384029 (TR2) & var. 1 & var. 2 & var. 1 & OTU3 \\
\hline A.compactum FJ384032 (UAc) & var. 3 & var. 2 & var. 2 & OTU4 \\
\hline
\end{tabular}

"Ukrainian cultivar" (FJ384032) also represents the separate OTU, but the origin of this specimen remains unknown. [FRAJMAN et al., 2009]. Whereas herbarium sample, collected near Sevastopol (KW № 014166) is identical by morphological features to $A$. compactum from Caucasus, we assume that this species is cultivated on the territory of Ukraine. But the origin of the specimen FJ384032 as "Ukrainian cultivar" [FRAJMAN et al., 2009] exactly from Ukraine is still under question.

\section{Conclusions}

The comparative search of 29 herbarium specimens of $A$. compactum from Caucasus and $A$. hypanicum from the valley of Pivdenny Bug confirmed the presence of morphological differences, connected with structure of bracts and apical (upper) leaves between the two taxa. We determined that features such as tooth shape of calyx, bract length and ratio between calyx and capsule length, proposed earlier for discrimination of these species, cannot be used as diagnostic and discriminative.

Provided reconstruction of ITS1 and ITS2 secondary structures has shown that there were no CBC between $A$. hypanicum and A. compactum. This fact supports the absence of any genetic barriers for breeding according to A. Coleman concept.

$A$. hypanicum can be separated from all investigated $A$. compactum sequences by the structural nucleotide substitution in the 4-th helix of ITS2.

Thereby, provided comparative morphological and molecular genetic study confirmed A. hypanicum as a separate species and its endemism.

\section{Acknowledgments}

The authors express gratitude to Sergei L. Mosyakin, Prof., Dr.Sci. Corr. Member, Natl. Acad. Sci. of Ukraine, Director, M.G. Kholodny Institute of Botany and to Nataliia M. Shyyan, $\mathrm{PhD}$, curator of National herbarium of Ukraine $(\mathrm{KW})$ for providing a specimen of A. hypanicum. 
References
Altschul S.F., Gish W., Miller W. et al. (1990). Basic Local Alignment Search Tool. J. Mol. Biol., 215: 403410.

Bilz, M., Kell, S.P., MaXted, N. et al. (2011). European Red List of Vascular Plants. Luxembourg: Publications Office of the European Union. $130 \mathrm{p}$.

BYUN Y., HAN K. (2009). PseudoViewer3: generating planar drawings of large-scale RNA structures with pseudoknots. Bioinformatics, 25: 1435-1437.

Chervona knyga Ukrainy. Roslynnyi svit (2009). Kyiv: Globalkonsaltyng: 900 p. [Червона книга України. Рослинний світ. (2009). Київ: Глобалконсалтинг: 900 с.]

Chervona knyga Ukrainy. Roslynnyi svit (1996). Kyiv: Ukrainska entsyklopedia: 608 p. [Червона книга України. Рослинний світ. (1996). Київ: Українська енциклопедія: 608 с.]

Coleman W.A. (2009). Is there a molecular key to the level of "biological species" in eukaryotes? A DNA guide. Molecular Phylogenetics and Evolution, 50: 197-203.

Coleman W.A. (2007). Pan-eukaryote ITS2 homologies revealed by RNA secondary structure. Nucleic Acid Research, 53 (10): 3322-3329.

COLEMAN W.A. (2003). The significance of a coincidence between evolutionary landmarks found in mating affinity and a DNA sequense. Protist, 151: 1-9.

GotTsChling M., PlÖtNer J. (2004). Secondary structure models of the nuclear internal transcribed spacer regions and 5.8S rRNA in Calcioidinelloideae (Peridiniaceae) and other dinoflagellates. Nucleic Acids Res., 32 (1): 307-315.

EUROPEAN Red List of globally threatened animals and plants and recommendations on its application as adopted by the Economic Commission for Europe at its forty-sixth session (1991). New York: United Nations. 154 p.

FEDORONCHUK M.M. (1997). Ukr. botan. zhurn., 54 (6): 557-564. [ФЕДОРончук M.M. (1997). Silene L. sensu lato в Україні: огляд роду Silene sensu stricto (Caryophyllaceae). Укр. ботан. журн., 54 (6): $557-$ 564.]

FedoronchuK M.M., Didukh Ya. P. et al. Ekoflora Ukrainy. 3. К.: Phytosociocentr: 496 p. [ФЕДорончук М.М., Дıдух Я.П. та ін. (2002). Екофлора України. 3. К.: Фітосоціоцентр: 496 с.]

FLORA Vostochnoy Yevropy (2004). Moskva - Sankt-Peterburg: Tovaryshchestvo nauchnych izdanii KMK. [ФЛоРА Восточной Европы (2004). Москва - Санкт-Петербург: Товарищество научных изданий КМК. 11: 536 c.]

FLORA of Turkey and the East Aegean Islands (1967). Vol. 2. Edinburg: Edinburgh University Press: 581.

FLORA SSSR (1936). Moskva-Leningrad: Izd. AN SSSR. 6: 956 с. [ФЛОРА СССР (1936). Москва-Ленинград: Изд. АН СССР. 6: 956 c.]

FLORA URSR (1952). Kyiv: Vyd-vo AN URCR. 4: 689 с. [ФлоРА УРСР (1952). Київ: Вид-во АН УРСР. 4 : 689 c.]

Frajman B., Heidari N., Oxelman B. (2009). Phylogenetic relationships of Atocion and Viscaria (Sileneae, Caryophyllaceae) inferred from chloroplast, nuclear ribosomal, and low-copy gene DNA sequences. Taxon, 58 (3): 811-824.

HALl T.A. (1999). BioEdit: a user-friendly biological sequence elignment editor and analysis program for Windows 95/98/NT. Nucleic Acids Res., 41: 95-98.

KLoKov M.V. (1948). Botan. zhurn., 5 (1): 20-28. [Клоков М.В. (1948). Нові матеріали до пізнання Української флори. Нові види з родин гвоздичних, гречкових і хрестоцвітих. Ботан. журн., 5 (1): 20-28]

Mosyakin S.L., FedoronchuK M.M. (1999). Vascular plants of Ukraine. A nomenclatural checklist. Kiev. $345 \mathrm{p}$.

OPREDELITEL vysshyh rasteniy Ukrainy (1987). Kiev: Naukova dumka: 548 p. [ОПРедЕЛИтель высших растений Украины (1987). Киев: Наукова думка: 548 с.]

TARIeIEv A.S., Girin A.S., KARPEnKo et al. (2011). Chornomors'k. bot. z., 7 (4): 309-317. [TAPE€B A.C., ГІРІН А.С., КАРПЕНКО Н.І. та ін. (2011). Модифікована методика виділення ДНК з гербарних зразків. Чорноморськ. бот. ж., 7 (4): 309-317]

Tutin, T.G., HeYwood, V.H., Burges, N.A. et al. (1993). Flora Europea. 2nd ed. 1. Cambridge: Cambridge University Press. $585 \mathrm{p}$.

Tzvelev N.N. (2001). Novosti sistematiki vyssh. rast., 33: 90-113. [ЦвеЛЕВ Н.Н. (2001). О родах трибы Смолевковых (Sileneae DC., Caryophyllaceae) в Восточной Европе. Новости систематики выси. pacm., 33: 90-113]

White T. J., BRUnS T., LeE S., TAYlor J. W. (1990). Amplification and direct sequencing of fungal ribosomal RNA genes for phylogenetics. PCR Protocols: A Guide to Methods and Applications. Academic Press, Inc., New York: 315-322. 
Taxonomic status of Atocion hypanicum (Klokov) Tzvelev (Caryophyllaceae) inferred from analysis of ITS1 and ITS2 secondary structure

ZUKER M. (2003). Mfold web server for nucleic acid folding and hybridization prediction. Nucleic Acids Research., 31 (13): 3406-3415.

Рекомендує до друку

Отримано 25.11.2014

О.С. Ходосовцев

Aдреса авторів:

B.О.Мартинюк

O.B. Тищенко

H.I. Карпенко

A.C. Tapeeв

I.Ю. Костіков

Киїський національний університет

імені Тараса Шевченка

вул. Володимирська, 64

Київ, 01601, Україна

e-mail:vikamartynuk@ukr.net

oksanat1@ukr.net

karpenko563@gmail.com

andrey_tareev@univ.kiev.ua

kost@univ.kiev.ua

Authors' address:

V.O. Martynyuk

O.V. Tyshchenko

N.I. Karpenko

A.S. Tareev

I.Yu. Kostikov

Taras Shevchenko National University of Kyiv

64, Volodymyrs'ka str.

Kyiv, 01601, Ukraine

e-mail:vikamartynuk@ukr.net

oksana_t@ukr.net

karpenko563@gmail.com

andrey_tareev@univ.kiev.ua

kost@univ.kiev.ua 